\title{
DOES CORPORATE GOVERNANCE MATTER? A CRUDE TEST USING RUSSIAN DATA
}

\author{
BERNARD BLACK ${ }^{\dagger}$
}

\begin{abstract}
Does a firm's corporate governance behavior affect its market value? In most empirical tests in developed countries, firm-specific corporate governance actions have little or no effect on market value. These weak results could reflect limited variation among firms in governance practices.

In contrast, the corporate governance practices of Russian firms vary widely, from quite good to awful. I test whether corporate governance behavior affects the market value of Russian firms using (1) fall 1999 corporate governance rankings developed by a Russian investment bank for sixteen Russian public companies and (2) the "value ratio" of actual market capitalization to potential Western market capitalization for these firms, determined independently at the same time by a second Russian investment bank. The correlation between In(value ratio) and governance ranking is striking and is statistically strong despite the small sample size: Pearson $r=0.90(p<.0001)$. A one-standard-deviation improvement in governance ranking predicts an 8-fold increase in firm value; $a$ worst (51 ranking) to best ( 7 ranking) governance improvement predicts a 600 -fold increase in firm value. My results are tentative, due to the small sample size. But they suggest that a firm's comporate governance behavior can have a huge effect on its market value in a country where other constraints on corporate behavior are weak.
\end{abstract}

\section{INTRODUCTION}

Does a firm's corporate governance behavior-defined broadly to include both the governance rules that the firm adopts and the behavior of its insiders along governance-related dimensions-affect its market value? For United States firms, evidence that governance

† Professor of Law, Stanford Law School. Special thanks to James Fenkner of Troika Dialog for providing the valuation data used in this Article and Andrea Rutherford of Brunswick Warburg for discussing with me the basis for their corporate governance rankings. I thank Cindy Alexander, Jack Coffee, Stephen Deane, John Donohue, Jeff Gordon, Avery Katz, Alexander Raskovitch, Eric Talley, participants in the University of Pennsylvania Law School Symposium on Norms and Corporate Law (Dec. 2000), and participants in workshops at Chicago-Kent Law School, Columbia Law School, Georgetown Law School, the United States Department of Justice, Antitrust Division, and USC Law Center for their comments and suggestions. A more technical version of this Article, using an expanded twenty-one firm sample, will be published as Bernard Black, The Corporate Governance Behavior and Market Value of Russian Firms, 2 EMERGING MARKETS REV. (forthcoming 2001), available at http://papers.ssrn.com/paper.taf?abstract_id=263014 (Social Science Research Network). 
practices matter is scarce. Most tests of whether interfirm variations in corporate governance practices affect firms' market value or performance come up empty. When effects are found, they are economically small—often only a percent or two.

And yet, perhaps the problem is with the data, not the proposition that firms' corporate governance behavior affects their market value. The minimum quality of American corporate governance, set by law and by norms so widely accepted that almost no public firms depart from them, is quite high. The variation in firm behavior is small, perhaps too small for us to observe large performance differences due to this variation.

A stronger test of whether and by how much governance behavior affects firms' market value could be possible in a country with weak laws governing behavior by firms and their insiders (managers and large shareholders), weak norms for insider conduct, and weak reputational constraints on insider conduct. In such a country, governance differences between firms will be larger and could have measurable effects on market value.

Across all three dimensions, Russia offers a strong test case. Its corporate and securities laws are unenforced and widely ignored. Behavioral norms reinforce bad behavior-self-dealing and often outright looting. And insiders didn't need to develop reputations for honesty so that their firms could sell shares to the public. Instead, major companies were sold in privatization auctions, letting even disreputable insiders acquire control. The low minimum quality of Russian corporate governance leaves huge room for interfirm variation. Some insiders will simply loot their firms; others will try to attract investors through good conduct; still others will steal some but not all of the firm's profits.

This Article tests the proposition that corporate governance behavior affects the market value of Russian firms (the value that outside, noncontrolling shareholders pay for the firm's shares). I use fall 1999 corporate governance rankings for a sample of sixteen large Russian public companies, developed by Brunswick Warburg, a major Russian investment bank. These estimates were not directly, and their creators believe that they were not indirectly, influenced by the firms' market values.

I combine these governance rankings with data on the actual

' See generally Bernard Black, Reinier Kraakman \& Anna Tarassova, Russian Privatization and Corporate Governance: What Went Wrong?, 52 STAN. L. REv. 1731 (2000). 
September 1999 market capitalization of these firms and estimates by Troika Dialog, a second major Russian investment bank, of these firms' potential Western market capitalization at that time. The potential Western capitalization is based on the multiples of assets, capacity, or revenue at which Western firms trade. I see no way for a Russian firm's governance behavior to affect these estimates.

The "value ratio" of actual to potential Western market capitalization offers a measure of the discounts that investors apply to these firms. The variation in discounts is huge-the value ratios vary from 0.48 for Vimpelcom to 0.0001 for Yuganskneftegaz.

The correlation between these firms' value ratios and their corporate governance rankings offers a measure of how important corporate governance behavior is, when investors value Russian firms. The correlation is striking. The Pearson product-moment correlation coefficient between $\ln$ (value ratio) and governance ranking is $r=0.90$, with a $t$-statistic of 7.63 (significance level of $p<.0001$ ). These results survive various robustness checks.

My results are tentative because of the small sample size. But they suggest that the governance behavior of Russian firms greatly affects their market value. A measure of how much: a one-standarddeviation change in governance ranking predicts an 8-fold increase in firm value. A worst (51 ranking) to best ( 7 ranking) change in governance ranking predicts a 600 -fold increase in firm value!

This Article proceeds as follows. Part I offers a brief overview of research in the United States on the extent to which corporate governance attributes correlate with firms' market value or performance. Part II describes my research design. Part III presents results. Part IV concludes and discusses policy implications and possible extensions of this research.

\section{DOES CoRPorate GOVERNANCE BEHAVIOR AFFECT FIRM VALUE?}

\section{A. Evidence from the United States}

In the United States, efforts to find a correlation between a firm's governance attributes and its market value mostly show weak or no results. For example, the proportion of independent directors on a company's board (or whether the company has a majorityindependent board) has no statistically significant effect on 
performance. ${ }^{2} \quad$ Similarly, neither overt activism by institutional investors, nor insider share ownership, nor ownership by outside blockholders, nor a firm's committee structure, has a measurable effect on performance. ${ }^{3}$

When effects are found, they are usually small-a percentage point or two difference in market value. Effects of this size are found, for example, for a staggered board or other antitakeover provisions, incorporation in Delaware, ${ }^{5}$ or use of cumulative voting."

\section{B. Governance Behavior Should Matter More in Emerging Markets}

The weak observed correlation between the corporate governance practices of U.S. firms and their market value or performance could

${ }^{2}$ See the reviews by Sanjai Bhagat \& Bernard Black, The Uncertain Relationship Between Board Composition and Firm Performance, 54 BUS. LAW. 921 (1999), and MICHAEL S. WEISBACH \& BENJAMIN E. HERMALIN, BOARDS OF DIRECTORS AS AN ENDOGENOU'SLY DETERMINED INSTTUUTION: A SURVEY OF THE ECONOMIC LITERATURE (Nat'1 Bureau of Econ. Research, Working Paper No. W8161, 2001), available at http:// papers.ssrn.com/paper.taf?abstract_id=262721 (Social Science Research Network).

${ }^{3}$ On institutional investor activism, see the surveys by Bernard Black, Shareholder Activism and Corporate Governance in the United States, in 3 THE NEW PALGRAVE DicTIONARY OF ECONOMICS AND THE LAW 459 (Peter Newman ed., 1998), and Jonathan Karpoff, The Impact of Shareholder Activism on Target Companies: A Survey of Empirical Findings (1998), http://faculty.washington.edu/karpoff/papers.htm. On the complex relationship between inside ownership and firm value, see, for example, Harold Demsetz \& Kenneth Lehn, The Structure of Corporate Ownership: Causes and Consequences, 93 J. POL. ECON. 1155 (1985), and Randall Morck, Andrei Shleifer \& Robert W. Vishny, Management Ownership and Market Valuation: An Empirical Analysis, 20 J. FIN. ECON. 293 (1988). On outside blockholdings, see, for example, Sanjai Bhagat, Bernard Black \& Margaret Blair, Relational Investing and Firm Performance (1998) (unpublished manuscript, on file with author). On board committees, see April Klein, Firm Performance and Board Committee Structure, 41 J.L. \& ECON. 275 (1998).

${ }^{4}$ See, e.g., Sanjai Bhagat \& Richard H. Jefferis, Voting Power in the Proxy Process: The Case of Antitakeover Charter Amendments, 30 J. FIN. ECON. 193 (1991); Robert Daines \& Michael Klausner, Do IPO Charters Maximize Firm Value? Antitakeover Protection in IPOs, J.L. ECON. \& ORG. (forthcoming 2001), available at http://papers.ssm.com/ paper.taf?abstract_id=187348 (Social Science Research Network); Robert Daines, Do Classified Boards Affect Firm Value? Takeover Defenses After the Poison Pill (2000) (unpublished manuscript, on file with N.Y.U. Center for L. \& Bus.) (finding a $-1.5 \%$ average price reaction to a Massachusetts law imposing staggered boards on all Massachusetts firms).

${ }^{5}$ See Robert Daines, Does Delaware Law Improve Firm Value?, J. FIN. ECON. (forthcoming 2001) (finding a $+2 \%$ effect of incorporation in Delaware on firm value, with outliers excluded), available at http://papers.ssrn.com/paper.taf?abstract_id= 195109 (Social Science Research Network).

'See Sanjai Bhagat \& James A. Brickley, Cumulative Voting: The Value of Minority Shareholder Voting Rights, 27 J.L. \& ECON. 339 (1984) (finding a -1.5\% average share price reaction to a charter amendment that eliminates cumulative voting). 
mean that firms' corporate governance behavior has only a small effect on their market value, compared to other elements such as industry environment, macroeconomic factors, and management skill. But the weak correlation could also reflect the restricted domain of the data. Within a single country, with a well-developed corporate governance system, differences among firms in corporate governance practices may be limited.

In the United States, the minimum quality of corporate governance, set by securities law, corporate law, stock exchange rules, and behavioral norms so widely accepted that almost no public firms depart from them, is quite high. The variation among firms could be too small for performance differences to emerge from the large amount of "noise" (other factors that affect firm performance) that afflicts empirical studies in this area.

To conduct a stronger test, we ought to study a country with weaker laws governing behavior by firms and insiders, weaker widely accepted norms for insider conduct, and weaker reputational constraints on insiders. Governance differences among firms will be larger and the effects of interfirm variation on firms' market value or performance will likely be larger as well.

Across all three dimensions, Russia offers as close to an ideal test case as we are likely to find. It has decent corporate and securities laws, but the laws are unenforced and widely ignored. Cultural norms among managers and large shareholders reinforce bad rather than good behavior. Self-dealing and often outright looting is the norm, not the exception. And insiders didn't need to develop reputations for honesty in order to sell shares to the public. Instead, major companies were sold through privatization auctions, which let even disreputable insiders acquire control in the privatization auctions or thereafter. Indeed, control of many major companies was sold directly to crooks, who got the money to buy them by skimming or outright theft from the government. ${ }^{7}$

Put these factors together and Russia ranked last in a recent survey of corporate governance practices in twenty-five emerging markets. ${ }^{\mathrm{N}}$ Russian investment banks routinely write reports with such charming titles as Corporate Governance in Russia: Cleaning Up the Mess.

${ }^{7}$ See Black, Kraakman \& Tarassova, supra note 1, at 1742-46.

" See Boris the Belligerent, Economist, Nov. 18, 2000, at 80; Craig Karmin, ComporateGonemance Issues Hamper Emerging Markets, WALL ST. J., Nov. 8, 2000, at C1.

"James Fenkner \& Elena Krasnitskaya, Corporate Governance in Russia: Cleaning Up the Mess (1999) (unpublished corporate report for Troika Dialog, on file with 
The low quality of Russian governance practices leaves huge room for interfirm variation. Some insiders will loot their firms; others will try to attract investors through good conduct; still others will behave more or less typically by Russian standards (stealing some but not all of a firm's profits).

The large variation in Russian corporate governance leads investors to place heavy weight on a firm's governance behavior in deciding which firm's shares to buy and how much to pay. The qualitative evidence for investor concern includes:

(1) frequent reports on corporate governance issued by Russian investment banks, including the rankings and other reports discussed here, and the weekly Corporate Governance Bulletin issued by the Troika Dialog investment bank, which discusses current governance issues affecting particular Russian firms; and

(2) the announcement by Standard \& Poor's that it is developing its own corporate governance rankings of Russian firms."

This Article can be understood as an effort to see whether that qualitative insight will translate into quantitative data that supports the proposition that the corporate governance behavior of Russian firms affects their market value.

\section{RESEARCH DESIGN}

My goal is to test whether interfirm variation in corporate governance behavior has a significant effect on the market value of Russian firms-and by inference, likely also the market value of firms in other countries with weak corporate governance laws and norms. I rely on two datasets, generated independently by two prominent Russian investment banks.

\section{A. Russian Corporate Governance Rankings}

The first data set is fall 1999 corporate governance rankings of sixteen major Russian firms, developed by the Brunswick Warburg

author).

10 See Press Release, Standard \& Poor's, Standard \& Poor's Launches Corporate Governance Services in Russia (Nov. 14, 2000) (on file with author); see also Lyuba Pronina, SE'P Test Flies Governance Rating on Aeroflot, MOSCOW TIMES, Mar. 21, 2001. 
investment bank." Brunswick Warburg rated Russian companies on a 0 to 60 scale, with higher numbers indicating higher governance risk. The risk factors that influence the rankings and the maximum weight given to each risk factor are listed in Table 1. The risk factors are consistent with the view, which I have expressed elsewhere, that corporate governance concerns in emerging markets focus on information disclosure and control of self-dealing, not on the developed country problem of persuading managers to maximize firm value. $^{\text {i2 }}$

The firm rankings are shown in Table 2. The highest ranking is 7 for Vimpelcom, which conducted an initial public offering in the United States, is listed on the New York Stock Exchange, and publishes financial statements using U.S. Generally Accepted Accounting Principles ("GAAP"). The lowest rankings are 51 for three subsidiaries of Yukos: Yuganskneftegaz, Samaraneftegaz, and Tomskneft. During 1999, Yukos's controlling shareholder, Mikhail Khodorkovski, was trying to transfer virtually all value from these subsidiaries (and perhaps from Yukos itself) to shady offshore companies. ${ }^{13}$ The Appendix provides a detailed breakdown of the risk factors that enter each firm's overall ranking.

Potential bias in the regression results. None of the ranking elements directly involves a firm's market value. Most elements rely primarily on objective factors. For example, the dilution-through-share-issuance risk factor uses as subfactors the existence of authorized but unissued shares, the existence of preemptive rights, and minority investors holding a blocking stake (a stake large enough to defeat a charter amendment that would authorize additional shares). The Brunswick Warburg report gives no hint that firms' market values entered the rankings indirectly, through the choice or weighting of the corporate governance risk factors. To further exclude the possibility that market values indirectly influenced the rankings, I contacted Andrea Rutherford, the report's principal author, who confirmed that: "We did not use [market] valuations in any of our corporate governance

"S't' Andrea C. Rutherford \& Jeffrey R. Costello, Measuring Corporate Governance Risk in Russia (Aug. 30, 1999) (unpublished corporate report for Brunswick Warburg, on file with author).

'Bernard S. Black, The Legal and Institutional Preconditions for Strong Struriti's Markets, 48 UCLA L. REv. 781 (2001), available at http:// papers.ssrn.com/paper.tafPabstract_id=182169 (Social Science Research Network); see John C. Coffee, Jr., Privatization and Corporate Governance: The Lessons from Securities Makt Failure, 25 J. CoRP. L. 1, 17 (1999).

Ske Black, Kraakman \& Tarassova, supra note 1, at 1769-72. 
'scorings.' I have thought about each item and am sure that valuations could not have 'crept' in indirectly either."

\section{Table 1: Elements of Corporate Governance Risk}

\section{Risk Category}

Disclosure and Transparency

No current U.S. GAAP or IAS financials

Poor reputation for openness

No ADR program

Poor shareholder meeting notice

Total

Dilution Through Share Issuance

Authorized but unissued shares

No portfolio investor blocking stake

No preemptive rights in charter

Total

Asset Stripping and Transfer Pricing

Controlling shareholder (private $=5$, gov't $=3$ )

Works with trading companies

Total

Dilution Through Merger or Restructuring

Merger planned or possible

Restructuring planned or possible

Total

Bankruptcy Risk

Overdue accounts payable or tax arrears

High overall debt

Total

Limits on Foreign Ownership

Restricts foreign ownership or voting

Restricts foreign board membership

Total

Management Attitude Toward Shareholders

Poor corporate governance record

No outsider investor representatives on board

Total

Registrar Risk (Registrar Affiliated with Co.)

Total
Maximum Weight

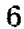

4

2

2

14

5

3

2

10

5

5

10

5

5

10

3

2

5

3

2

5

3

2

5

$\underline{1}$

60

B. Ratio of Actual to Potential Market Capitalization

The second data set consists of value ratios for these sixteen firms

${ }^{14}$ Letter from Andrea Rutherford, Head of Sales, Brunswick Warburg, to Bernard Black (Dec. 21, 2000) (on file with author). 
in September 1999 (matching the date of the corporate governance rankings). The value ratio is computed as the ratio of (1) actual market capitalization, based on trading prices in the Russian stock market, to (2) potential Western market capitalization, if the firm were "operated and valued in an efficient . . . western market."

The Western market capitalization estimates were provided to me by James Fenkner, Head of Equity Strategies at Troika Dialog, a major Russian investment bank. Russian financial statements are often opaque and many firms aren't run to maximize profit (at least unskimmed profit). Troika Dialog therefore based the potential Western market capitalization values on multiples of assets, capacity, or (for telephone companies) sales, rather than multiples of cash flow or profit. Table 2 shows these firms' actual September 1999 market capitalization, their potential Western market capitalization, and the Western-firm multiples used to compute each firm's potential Western market capitalization. Table 2 also gives each firm's value ratio and governance ranking.

An eyeball examination of Table 2 shows a strong correlation between value ratio and governance ranking. Oil and gas companies dominate the bottom of the value ratio rankings and also predominate as the firms with the highest (worst) governance rankings. There is huge potential value in Russian companies, but outside shareholders expect to receive very little of that value. A country with potential market capitalization of around $\$ 3$ trillion (including other companies not included in my sample) has an actual market capitalization of under $\$ 30$ billion.

E-mail from James Fenkner, Head of Equity Strategies, Troika Dialog, to Bernard Black (Mar, 7, 2001) (on file with author). 


\section{Table 2: Governance Rankings and Potential Value for Selected Russian Companies (at September 1999; in $\$$ billions)}

Governance rankings (from Brunswick Warburg) and potential Western market capitalization estimates (from Troika Dialog) for selected major Russian companies. Potential Western market capitalization is based on Troika Dialog's estimates of Western multiples of assets, capacity, or revenue: for oil and gas companies on $\$ 13$ per barrel of oil reserves (or gas equivalent); for electric companies on $\$ 795,000$ per megawatt of generating capacity; for Norilski Nickel on $0.085 \mathrm{x}$ value of reserves at then current commodity prices; for telephone companies on $4.3 \times$ sales; for GAZ on $\$ 4,620$ per vehicle produced; and for Sun Interbrew on $\$ 0.97$ per liter of capacity. Firms are listed in decreasing order of value ratio.

\begin{tabular}{|c|c|c|c|c|c|}
\hline \multirow[b]{2}{*}{ Company } & \multirow[b]{2}{*}{ Industry } & \multicolumn{2}{|c|}{$\begin{array}{c}\text { Market } \\
\text { Capitalization }\end{array}$} & \multirow{2}{*}{$\begin{array}{c}\text { Value Ratio } \\
\text { (Actual/Potential } \\
\text { Market Cap) }\end{array}$} & \multirow{2}{*}{$\begin{array}{c}\text { Govern- } \\
\text { ance } \\
\text { Ranking }\end{array}$} \\
\hline & & Actual & Potential & & \\
\hline Vimpelcom & Telephone & 0.58 & 1.2 & 0.48 & 7 \\
\hline Rostelecom & Telephone & 0.9 & 5 & 0.18 & 15 \\
\hline GAZ & Truck Mfg. & 0.11 & 0.7 & 0.16 & 17 \\
\hline Sun Interbrew & Alcohol Mfg. & 0.11 & 1.5 & 0.073 & 16 \\
\hline Mosenergo & Electricity & 0.8 & 12 & 0.067 & 15 \\
\hline Norilski Nickel & Nickel & 0.5 & 9 & 0.056 & 27 \\
\hline Surgutneftegaz & Oil & 4.4 & 91 & 0.048 & 26 \\
\hline Irkutskenergo & Electricity & 0.4 & 0 & 0.040 & 10 \\
\hline LukOil & Oil & 5.5 & 195 & 0.028 & 20 \\
\hline $\begin{array}{l}\text { United Energy } \\
\text { Systems }\end{array}$ & Electricity & 3.1 & 110 & 0.028 & 24 \\
\hline Sibneft & Oil & 1.1 & 60 & 0.018 & 25 \\
\hline Tatneft & Oil & 0.4 & 75 & 0.005 & 18 \\
\hline Gazprom & Natural Gas & 4 & 1960 & 0.002 & 38 \\
\hline Tomskneft & Oil & 0.039 & 24 & 0.0016 & 51 \\
\hline Samaraneftegaz & Oil & 0.003 & 18 & 0.0002 & 51 \\
\hline Yuganskneftegaz & Oil & $\underline{0.014}$ & 110 & $\underline{0.0001}$ & 51 \\
\hline Total & & 22.0 & 2682 & Mean $=0.07$ & Mean $=26$ \\
\hline
\end{tabular}

Potential bias in the regression results. The actual market capitalization of these firms is based on actual trades. The potential Western market capitalization is constructed by Troika Dialog based on objective facts about the Russian firms-estimates of reserves, 
capacity, or revenue. Troika Dialog chose the multiples of reserves, capacity, or revenue by looking at Western firms, not Russian firms. Moreover, Troika Dialog did not know the sample firms' governance rankings or the basis for the governance rankings. Indeed, Troika Dialog initially created the potential Western market capitalization values, at my request, for an entirely separate project-an earlier article on what went wrong with Russian privatization. ${ }^{16}$ For all these reasons, I don't see how the governance attributes of the sample firms could affect Troika Dialog's estimate of their potential Western market capitalization.

\section{Sample Statistics}

Table 3 presents simple statistics for my sample on the value ratio, a logarithmic transformation of the value ratio, and the governance ranking. I use a logarithmic transformation of the value ratio to test the correlation between governance and firm value for two reasons. First, the raw value ratio is restricted to the $[0,1]$ interval, and highly skewed (most observations are near the lower end of this range). It does not satisfy the normality assumptions that underlie regression analysis. Second, the raw value ratio gives very little weight to differences in value at the low end of the value range. For example, the 100-fold difference between a value ratio of 0.0001 and 0.01 counts about the same as the 2-fold difference between 0.01 and 0.02 .

Table 3: Summary Statistics

\begin{tabular}{lccc}
\multicolumn{1}{c}{ Variable } & Mean & $\begin{array}{c}\text { Standard } \\
\text { Deviation }\end{array}$ & $\begin{array}{c}\text { Number of } \\
\text { Observations }\end{array}$ \\
Value Ratio & 0.07 & 0.121 & 16 \\
Ln(Value Ratio) & -4.09 & 2.40 & 16 \\
Governance Ranking & 26 & 14.5 & 16
\end{tabular}

III. RESULTS

A. Basic Regression Results

The next step is to determine the correlation between governance

Rr Sir Black, Kraakman \& Tarassova, supra note 1, at 1768. 
ranking and In(value ratio). I test the hypothesis that high governance ranking (low governance quality) correlates negatively with $\ln$ (value ratio).

I run a simple regression (equivalent to computing the Pearson product-moment correlation coefficient $r$ ) of $\ln$ (value ratio), as the dependent variable, on governance ranking, as the independent variable. A constant term is the only other independent variable. The regression equation and related statistics are shown in Table 4. Figure 1 shows the raw data together with the fitted regression line. The Pearson correlation coefficient is -0.90 , with a correspondingly high $R^{2}$ of 0.81 . Statistical significance is very high $(t=-7.63)$ despite the small sample size.

Table 4: Regression: Ln(Value Ratio) on Governance Ranking

$$
\begin{aligned}
\ln (\text { value ratio })= & -0.281+(-0.148) \cdot(\text { governance ranking }) \\
& (t=-7.63)(p<.0001)^{17}
\end{aligned}
$$

$F(1,14)=58.24$

Pearson $r=-0.898\left(R^{2}=0.806\right.$; adj. $\left.R^{2}=0.792\right)$

${ }^{17}$ All significance levels for regression and correlation coefficients reported in this Article are for two-tail tests. 
Figure 1: Regression: ln(value ratio) on Governance Ranking (high ranking implies worse governance)

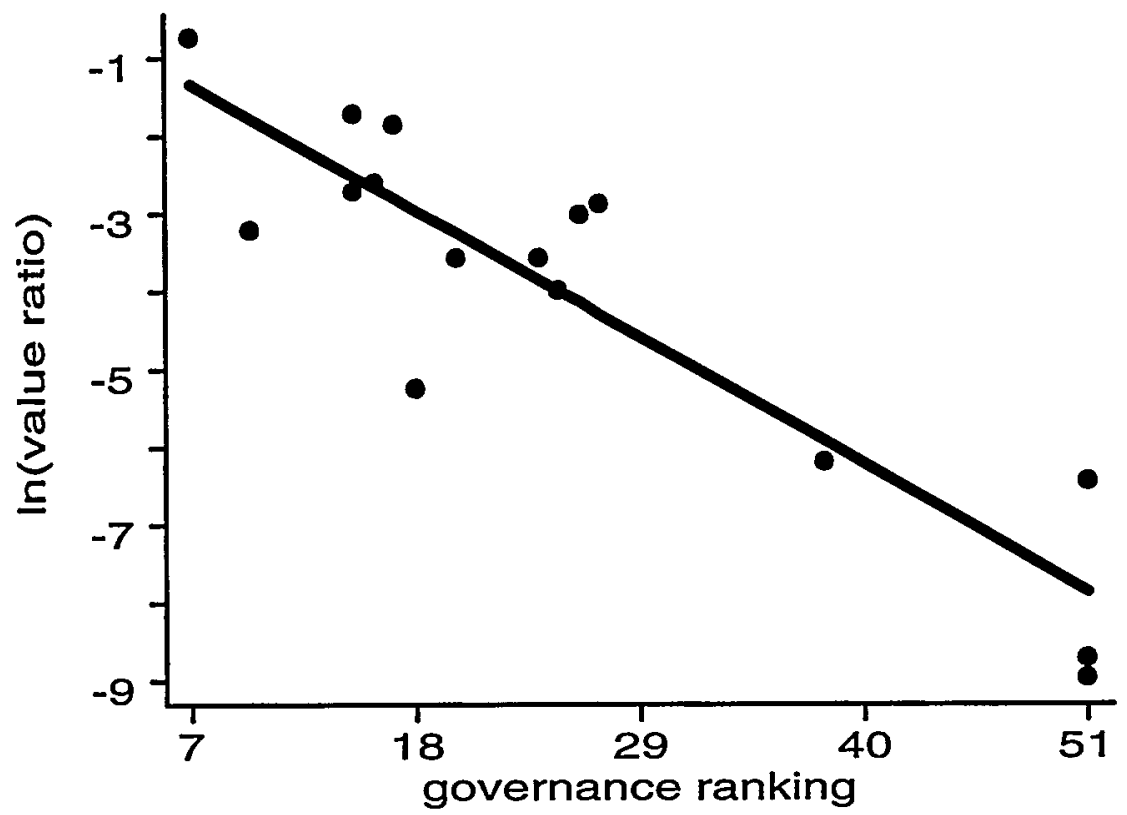

These results are tentative because of the small sample size. But they are surprisingly strong, given the crude nature of the governance rankings and the estimates of potential Western market capitalization, and the many factors that can affect firm value. In Russia, corporate governance behavior, as captured by the governance ranking, appears not only to affect firms' market value, but to be the dominant determinant of the value ratio.

The results are not only statistically strong, they are economically powerful. Converting the logarithmic regression to exponential form, it becomes:

$$
\text { value ratio }=0.755 \cdot e^{(-0.148) \cdot(\text { govemance ranking) }}
$$

An improvement (reduction) in governance ranking by one standard deviation-roughly 15 points-predicts an increase in firm value by a factor of $e^{(-0.148) \cdot(-1452)}=8.58$. A worst (ranking of 51) to best (ranking of 7) change in governance predicts an increase in firm value by a factor of $e^{(-0.148) \cdot(-4)}=673$.

Other (unobserved) factors affect the value ratio as well. The mean distance of the actual $\ln$ (value ratio) from the fitted regression line is $\mathbf{0 . 8 2}$. Thus, the actual value ratio differs from the value ratio 
predicted by the regression line, on average, by a factor of $e^{082}=2.3$. The maximum difference between the actual and predicted value ratio is a factor of 9.8. But the effect on market value of these unobserved factors, although economically large, pales compared to the apparent value effect of the governance ranking.

\section{B. Robustness Checks \\ 1. Normality Tests}

Least squares regression assumes that the dependent variable and (less critically) the independent variables are normally distributed. This assumption is reasonably satisfied by my data. Standard tests for normality fail to reject the hypothesis of normal distribution for both $\ln$ (value ratio) and governance ranking. Neither $\ln$ (value ratio) nor governance ranking shows significant skewness or kurtosis. For example, the commonly used Shapiro-Wilk $W$ test for normality produces insignificant $z$ statistics for both variables: $:^{18}$

$$
\begin{array}{llll}
\ln \text { (value ratio): } & W=0.905 & z=1.31 & (p=.10) \\
\text { governance ranking: } & W=0.913 & z=1.13 & (p=.13)
\end{array}
$$

\section{Alternative Measures of Correlation}

I also run two alternative specifications of the correlation coefficient that are less sensitive to whether the variables are normally distributed. First, I compute the Spearman rank-order correlation coefficient rho. The Pearson coefficient $r$ uses information about the distance of each data point from the mean for each variable. In contrast, the Spearman coefficient rho uses information only about the relative ranks of the data points. It is not affected by the logarithmic transformation of the value ratio and would not be affected by a similar transformation of the governance ranking. The results are again strong:

$$
\text { Spearman rho }=-0.804 \quad(t=-5.07 ; p=.0002)
$$

${ }^{18}$ Similar results (failure to reject the hypothesis of normality) are obtained from the D'Agostino-Royston test for normality used in the Stata statistics software, which combines skewness and kurtosis measures into an adjusted $\chi^{2}$. The computed values are $\chi^{2}=3.26(p=.20)$ for $\ln$ (value ratio) and $\chi^{2}=2.94(p=.23)$ for governance ranking. 
Second, I compute the Kendall $\tau$-b correlation coefficient, which relies on differences in rank order and is less dependent than either Pearson or Spearman on the distribution of the variables, again with strong results:

$$
\begin{aligned}
& \text { Kendall's } \tau-b=-0.627 \\
& \text { Kendall's score }=-74(\text { standard error }=22.11) \\
& z=74 /(22.11)=3.35(p=.001)
\end{aligned}
$$

3. Subsidiaries of Yukos

Three of the sixteen firms in my sample are publicly traded subsidiaries of Yukos, an oil holding company. I treat these three firms as separate because, although they have the same governance ranking, their value ratios range from 0.0001 (for Samaraneftegaz) to 0.0016 (for Tomskneft). This suggests that investors value them differently.

There are other possible ways to treat these firms. One alternative is to treat the three subsidiaries as a single firm, with value ratio equal to the mean for the three firms. If I do this, the $t$-statistic for the regression in Table 4 drops, which is expected because of the smaller sample size, but remains very strong at $t=-5.98$. The regression coefficient changes only slightly, from -0.148 to -0.153 .

\section{Table 5: Alternative Treatment of Yukos Subsidiaries}

$\begin{array}{cccc}\text { Regression } & \begin{array}{c}\text { Pearson } \\ \text { correlation }\end{array} & \begin{array}{c}\text { Number of } \\ \text { coefficient } \\ \text { ( } t \text {-value) }\end{array} & \begin{array}{c}\text { coefficient } \\ \text { observations }\end{array}\end{array}$

$\begin{array}{lccc}\begin{array}{l}\text { Basic analysis: include three } \\ \text { subsidiaries as separate firms }\end{array} & \begin{array}{c}-0.148 \\ (t=-7.63)\end{array} & -0.898 & 16 \\ \begin{array}{l}\text { Alternative: treat } \\ \begin{array}{l}\text { subsidiaries as single firm } \\ \text { with value ratio }=\text { average for } \\ \text { the three subsidiaries }\end{array}\end{array} \begin{array}{c}-0.153 \\ (t=-5.98)\end{array} & -0.865 & 14 \\ & & & \end{array}$

4. Possible Control Variables

A further robustness check involves adding additional control 
variables to the regression. One possibility is industry controls. This approach is problematic for two reasons. First, given the small sample size, one can quickly run out of degrees of freedom. Only oil ( 7 firms) or oil and gas combined ( 8 firms) have enough firms in the sample to make an industry control feasible.

A second reason for not using an industry control is that industry may proxy for governance risk. Commodity export industries, including oil and gas, are subject to a high degree of transfer pricing risk. The commodity can be sold to a middleman controlled by the insiders at a below-market price and then resold at market price. These transfer pricing schemes are a favorite way for Russian managers to pocket profits and avoid taxes. Thus, oil and gas companies may attract bad managers who welcome the opportunity to steal the company's cash flow.

Other potential control variables have similar problems. For example, the percentage stake held by the controlling shareholder affects the controlling shareholder's ability and incentive to self-deal. Thus, this variable would be a problematic control variable, even if share ownership data were available. Insider holdings ought instead to affect a firm's governance risk and indeed are one factor that enters Brunswick Warburg's governance rankings.

Having said this, rerunning my basic regression with an oil-and-gas dummy variable is a natural robustness check. Table 6 shows the results:

\section{Table 6: Regression: $\ln$ (value ratio) on Governance Ranking and Oil/Gas Dummy}

$$
\begin{aligned}
& \ln (\text { value ratio })=-0.392+(-0.123) \cdot(\text { governance ranking }) \quad(t=-4.97) \quad(p<.001) \\
& +(1.057) \cdot(\text { oil } / \text { gas dummy }) \quad(t=-1.52) \\
& F(2,13)=32.96\left(R^{2}=0.835 ; \text { adj. } R^{2}=0.810\right)
\end{aligned}
$$

The oil-and-gas dummy variable takes the expected negative coefficient, but is not statistically significant. The basic result remains. Governance ranking takes a large negative coefficient and is highly significant.

\section{Which Governance Elements Matter Most?}

A final step in analyzing this data set is to assess, within the constraints set by the small sample size, which risk factors are most 
important in explaining the overall correlation. I crudely divide the risk factors into:

(1) disclosure risk (each firm's disclosure and transparency subranking);

(2) self-dealing risk (the sum of each firm's subrankings for dilution through share issuance, asset stripping and transfer pricing, dilution through merger or restructuring, and bankruptcy); and

(3) other risks (the sum of each firm's subrankings for limits on foreign ownership, management attitude toward shareholders, and registrar risk).

An initial hypothesis, from prior theoretical work, ${ }^{19}$ is that disclosure risk and self-dealing risk will separately predict $\ln$ (value ratio). Table 7 shows the regression results. Only self-dealing risk is statistically significant. Surprisingly, disclosure risk has a negligible coefficient.

\section{Table 7: Regression: $\ln$ (value ratio) on Subcategories of Governance Risk}

$$
\begin{aligned}
& \ln (\text { value ratio })=0.284+(-0.218) \cdot(\text { self-dealing risk })(t=-5.03)(p<.001) \\
& +(-0.244) \cdot(\text { other risk) } \quad(t=-1.31) \\
& +(-0.001) \cdot(\text { disclosure risk) } \quad(t=-0.01)
\end{aligned}
$$

These results, although tentative because of the small sample, suggest that disclosure alone is of limited value in an environment where company insiders can readily loot the value of minority shares, despite reasonably full disclosure and ample press coverage. The subsidiaries of Yukos offer an example. They have the lowest value ratios and the lowest governance rankings in my sample. These firms' approximate oil and gas reserves are reasonably known. The looting of Yukos and its subsidiaries by its controlling shareholder, Mikhail Khodorkovski, was widely reported in both the Russian and Western press. Khodorkovski proceeded nonetheless. 


\section{FUTURE RESEARCH}

In developed countries, firm-level variation in corporate governance practices has a minor effect on market value. In Russia, firm-level variation in governance behavior appears to have a huge effect on market value. It is the dominant source of interfirm variation in the value ratio of actual market capitalization to potential Western market capitalization. What is true for Russian firms is likely true, perhaps to a lesser extent, for firms in other governancechallenged countries.

This can be seen as good news for firms in these countries. It suggests that they can greatly improve their own share values, and thus reduce their cost of equity capital, through a determined effort to improve their corporate governance practices.

Important extensions of this research are possible, in Russia and other countries. Within Russia, my sample was restricted to sixteen firms. Rankings for a larger number of Russian firms, especially governance rankings from a different source, will provide an important robustness check. ${ }^{20}$

Second, the Brunswick Warburg governance rankings depend on subrankings of firms for eight corporate governance elements. An extension of this work, not practical with this sample because of the limited degrees of freedom, would be to estimate how each governance element affects firm value. ${ }^{21}$ This analysis can become part of an overall assessment of what really matters in corporate governance. Third, industry control variables, also not practical to use in this study because of the small sample size, could help to identify which industries are at particular risk for corporate governance abuses.

The methodology used here can also inform the cross-country comparisons of corporate governance pioneered by La Porta, Lopezde-Silanes, Shleifer, and Vishny. ${ }^{22}$ An important issue in these studies

${ }^{20}$ Preliminary results from an expanded sample of twenty-one firms are consistent with the results reported here. See Black, supra note $f$.

${ }^{21}$ For a first effort in this direction, see $i d$.

22 See Rafael la PORTa, Florencio lopez-De-Sillanes, ANDREI SHleifer \&: ROBERT VISHNY, INVESTOR PROTECTION AND CORPORATE VALUATION (Nat'l Bureau of Econ. Research, Working Paper No. W7403, 1999), available at http://papers.ssrn.com/paper.taf?abstract_id=227583 (Social Science Research Network); Rafael La Porta, Florencio Lopez-de-Silanes \& Andrei Shleifer, Corporate Ownership Around the Worlä, 54 J. FIN. 471 (1999); Rafael La Porta, Florencio Lopez-deSilanes, Andrei Shleifer \& Robert Vishny, Agency Problems and Dividend Policies Around 
is how to measure the strength of a country's capital markets. The measures employed include stock market capitalization as a percentage of gross domestic product, the number of public companies per million inhabitants, and bid-asked spreads as a percentage of share price. The value ratio of actual to potential Western market capitalization, averaged over a country's major companies, is more difficult to compute than these measures. But it can provide a more direct measure of corporate governance quality, that could permit better tests of the importance of particular corporate governance rules (preemptive rights, cumulative voting, et cetera).

The evidence reported here on how much corporate governance behavior matters in Russia also has practical significance for investors in Russian firms. The huge value differences attributable to governance behavior (a 600-fold difference in predicted value between the worst- and best-ranked firms in my sample) suggest that investors can usefully devote far more attention than they have in the past to developing improved measures of governance behavior, and quantifying their expected effect on firm value.

APPENDIX

The table on the next page provides details about the corporate governance rankings of the sixteen firms in my sample. It lists each firm's score on the eight risk factors that enter into the overall governance ranking.

the World, 55 J. FIN. 1 (2000); Rafael La Porta, Florencio Lopez-de-Silanes, Andrei Shleifer \& Robert Vishny, Law and Finance, 106 J. POL. ECON. 1113 (1998); Rafael La Porta, Florencio Lopez-de-Silanes, Andrei Shleifer \& Robert Vishny, Legal Determinants of External Finance, 52 J. FIN. 1131 (1997). I review this and related research on the relationship between investor protection and the strength of securities markets in Black, supra note 12. 


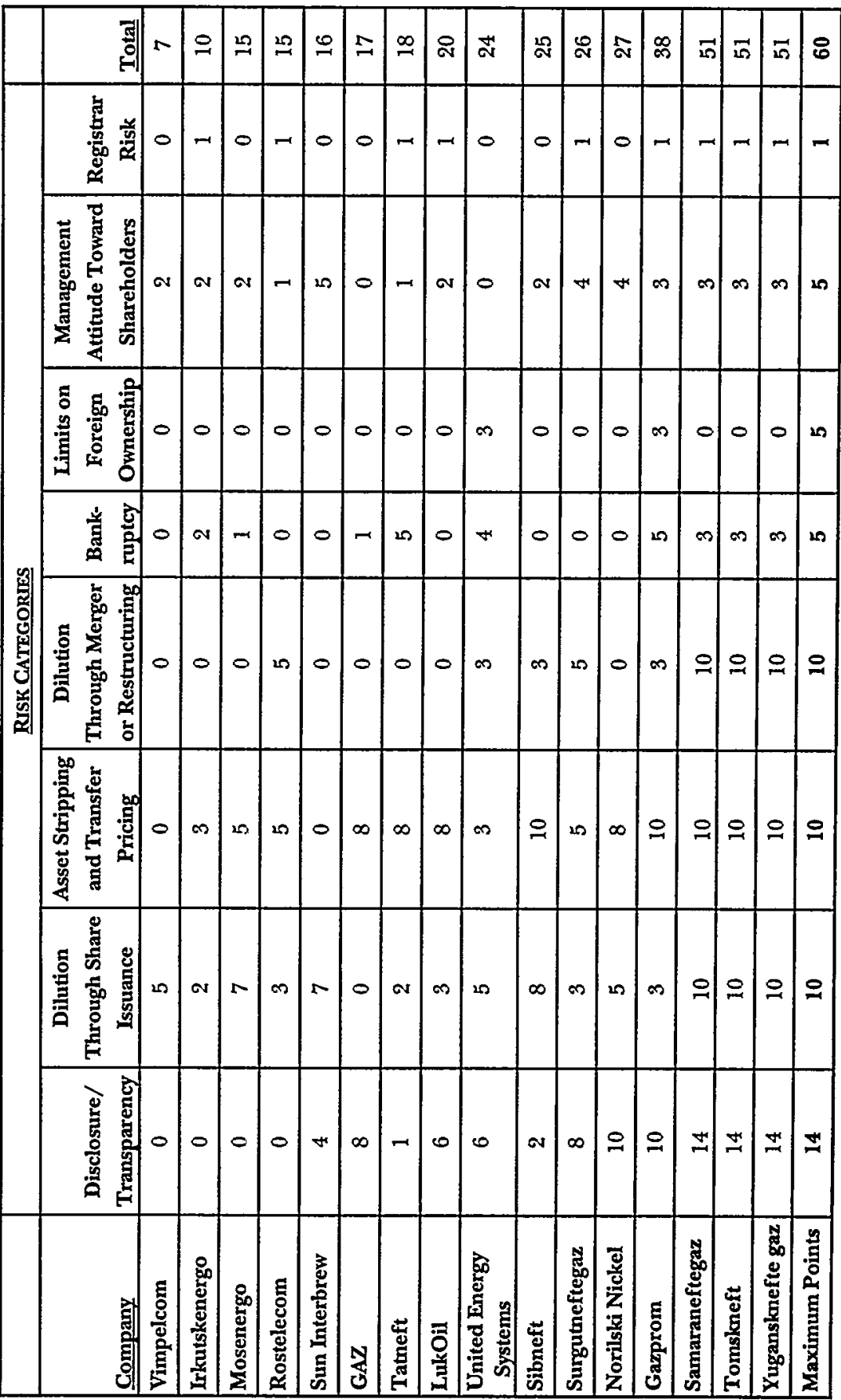

